\title{
TEACHERS' ELICITATION: INVITING STUDENTS TO SPEAK
}

\author{
Bustami Usman1 \\ Nour Ayouni ${ }^{2}$ \\ Iskandar Abdul Samad ${ }^{3}$ \\ Siti Sarah Fitriani 4 \\ English Education Department, Faculty of Teacher Training and Education, \\ Syiah Kuala University, Banda Aceh, Indonesia \\ 1bustami55@yahoo.com,2Nourayouni86@gmail.com, \\ 3iskandar.abdul.samad@unsyiah.ac.id, ${ }^{4}$ ssfitriani@unsyiah.ac.id
}

\begin{abstract}
This study describes the implementation of teachers' elicitation in speaking class of English Department of Ar-raniry Islamic State University. It attempts to investigate types of elicitation used by the lecturers in speaking class and the most frequent type. The participants of this study were five lecturers of speaking classes and hence ten teaching sessions were video-recorded and transcribed in order to analyze lecturers' utterance that indicates teachers' elicitation. Quantitative and qualitative method were employed where the data were obtained from observation and interview by means of video recorder, field-notes, observation sheet and interview guide. Technique of data analysis was followed Miles's \& Huberman's (1992) model including data reduction, data display, and conclusion. The results of this study revealed six types of elicitations; elicit:inform, elicit:confirm, elicit:agree, elicit:commit, elicit:repeat, and elicit:clarify were used by the lecturers in teaching speaking. It is also found elicit:inform was the most frequent type of elicitation used which reached $72.23 \%$. This indicates that the lecturers frequently used elicitation to invite students to speak.
\end{abstract}

Keywords: teachers' elicitation, types of elicitation, frequency, speaking class, English Department.

\section{INTRODUCTION}

Speaking as one of four language skills is very vital for both communication and language learning. Having good ability in speaking has been an indicator of students' successful in learning a language. As Goh and Burns (2012, p.1) stated that the mastery of speaking in English is a priority for second language learners. Their success in language learning is often evaluated on the basis of how well their spoken language proficiency. Ultimately, students are expected to have adequate skill in speaking which can be learnt from day-to-day interactive communication in the classroom.

Based on researcher's preliminary study in speaking class at English Department of Ar-raniry Islamic State University, students have limited chance to speak in the classroom where they are not invited to involve in the 


\section{EduLite}

teacher-students interaction. This is in line what Richard and Farrel (2011: 134) saying that students have only restricted opportunities to participate in the communicative and interactive uses of language and hence have restricted opportunities of language learning. As a consequence, they tend to be silent and listen to most teacher talk conducted by the lecturers in speaking class. Due to this, students could not practice some components such as grammar, vocabulary, pronunciation, language function, and also fluency of their English speaking.

Regarding this, speaking as the most important skill need to be taught by various strategies, one of them is by using elicitation effectively in the classroom by which lecturers can provide students great opportunity for practicing speaking. As Lindsay (cited in Syauqi, 2011, p. 19) proposes that speaking is introduced through three stages: elicitation of appropriate functional language, intensive oral practice, and developing oral fluency. By using elicitation, students are invited to be actively produced their language including grammar and vocabulary. As well, Nunan (1999, p. 306) asserts that elicitation is a procedure by which teachers stimulate students to produce sample of the structure, function, and vocabulary item being taught. Therefore, elicitation is essential to promote students' speaking skill.

Teachers' elicitation in language class does not only make active learning but also can develop students' language understanding. Their speaking proficiency can be trained through everyday teacher-students interaction during teaching and learning process. Classroom interaction and instructional conversation often includes teacher's elicitation which generate information, increase students' participation and greater students' cognitive development (Nathan and Kim, 2007, p. 6). Thus, lecturers can also monitor their progress including how they apply gammar items, how they use words, and also how they pnonounce them.

Elicitation enables lecturers to introduce those speaking elements by involving them directly in interactive conversations where lecturer usually asks questions, students answer to which is evaluated and corrected by the lecturer. It deals with various activities and many things can be elicited from students like information and ideas. Hence, speaking task, for example, dialogue is not presented to them but is elicited from them line by line using visual and verbal prompts. To construct a dialogue, some questions are asked to students to elicit the situation based on visual clues in the pictures (Thornburry, 2005, p. 77). Using elicitation in such speaking exercise is highly significant in which the lecturer elicits things from them instead of telling them. Besides, it increases more students' attention and participation.

Elicitation technique which requests for students' verbal response is commonly employed by the lecturers in speaking class to encourage their speaking. Some researchers have conducted studies on elicitation in English language classroom. A research has been conducted by Islamiyah (2012) in Content and Language Integrated Learning Classroom (CLIL). The results shown that over half of elicit:inform was used by the teachers which reached $58.7 \%$ of all, followed by elicit:confirm and elicit:agree with $21.8 \%$ and $7.5 \%$ respectively. This study revealed that the questions used by the teachers in CLIL classroom were posed by using some elicitations which aimed to guide 
Usman, Ayouni, Samad, Fitriani, Teachers' Elicitation: Inviting Students ...

the students involved in the lesson. Further, the different methods of teaching would result with different questions.

A research by Nurokhmah (2009) on English teachers of SMAN 3 Semarang revealed that the teachers mostly used elicit:inform in the form of WH question. Another similar research was done by Harahap (2010) in Biology Teaching in the International Standard Class of State Senior High School 1 Medan. It gave evidence that Biology teacher conducted elicitation in English Classroom interaction by questioning Yes/No question and $\mathrm{WH}$ question. Biology teacher conducted feedback in English classroom interaction by correction and elaboration, guided questioning, repeating correct answer, and encouragement.

Additionally, a research at King Abdulaziz University which was done by Alsubaie (2015) found that that teachers used three types of questions to elicit information from thier students. They are yes/no questions, closed/display questions and open-referential. It revealed that yes/no and closed/display question were used by the teachers more frequently than referential questions.

Regarding all above discussion, the researchers are therefore interested to conduct a qualitative and quantitive study on teachers' elicitation in speaking class. Hence, some research questions formulated for this study are as follow: (1) What kinds of elicitation are used by the lecturers in speaking class of English Department of Ar-raniry Islamic State University? (2) What kind of elicitation are most frequently used by the lecturers in speaking class of English Department of Ar-raniry Islamic State University?

Speaking is a way of conveying ideas, expressing feeling and sharing information by using spoken language. It is an essential mean of communication in daily life. In language learning, speaking is also important as parameter of someone's successful in mastering a target language. As Nunan (1999, p. 225) states "If listening is the Cinderella skill in second language learning, then speaking is the overbearing elder sister. The ability to function in another language is generally characterized in terms of being able to speak that language". Thus, students' mastery of English is often evaluated by the ability to speak it. That is why speaking as one of language skills become a primary skill to learn. It is at very heart of what it means to be able to use a foreign language (Luoma, 1999, p. 29).

To be proficiency in speaking, several components need to be noted on by both students and teacher when assessing. Nunan (1999, p. 226) suggested that what is it that one needs to know and be able to do in order to speak in another language? Of course, one needs to know how to articulate sounds in comprehensible manner, adequate vocabulary, and syntax mastery. Hence, grammar, vocabulary, and pronunciation are some elements that students need to apply appropriately in their speaking.

Ultimately, those aspects can be trained through kinds of speaking activities; transactional and interpersonal. Transactional functions to convey information and facilitate the exchange of goods and services (Harmer, 2007, p. 343). Meanwhile, accoording to Nunan (1999, p. 228), interpersonal has main purpose to maintain social rlationship. Students are expected to be able to use English in both genres. Speaking tasks in the classroom may be served in various activities so that they can experience language use in different 
contexts and situation. For instance, the lecturer can elicit ideas from students to build a dialogue by means of pictures or other visual aids. Therefore, the dialogue is developed by themselves instead of presenting it for them.

Elicitation

The term elicitation is firstly introduced by Sinclair and Coulthard in 1975 to describe utterances in the classroom which elicit verbal responses (Ramiro, 2002, p. 477). Further, Tsui (as in Jafari 2014, p. 3) adopted this term and defines it as any utterance whose function is to elicit an obligatory verbal response. In language classroom, elicitation is to encaurage students' speaking which is then their language competence can be evaluated. Nunan (1999, p. 306) describes that elicitation is a procedure by which teachers' stimulate students to produce sample of the structure, function, and vocabulary items being taught.

It is a standard procedure for the teachers to present the word meaning, for example by showing a picture and asking them to supply the form (Thornburry, 2013, p. 87). New words can be effectively presented by elicitation and that's why it is ver important to introduce vocabulary (Harmer, 2007, p. 229).

Lecturers in the classroom commonly use this technique to ask students to give information rather than telling them everything. Eliciting is as a technique of drawing things from students, generally by asking questions, instead of using teacher explanation. It leads to greater involvement, encourage thinking, and pushes sttudents to self discoveries (Scrivener, 2012, p. 139).

Briefly, elicitation in speaking class refers to any utterances which request students' verbal response including grammar and vocabulary to develop speaking skill. It increases more students' talking time and and the same time offers opportunities to practice speaking.

Elicitation takes biggest part of classroom interaction. It is commonly used to actively involve students in the teaching and learning process. Hence, the most common exchange in the classroom is eliciting exchange (Dailey, 2010). Obviously, it is very beneficial for language learning because it can facilitate students' speaking and provide large opportunity of language practice. To obtain students' verbal response, different kind of elicitation technique can be employed in speaking class such as asking question or providing stimulus e.g. picture, gestures, and setting up the discussion (Chitravelu, Sithamparan, and Choon, 2005).

Questions is the most popular way for lecturers to get students verbal response. Elicitation entails asking questions and it is one of the principal ways in which the teacher can control the classroom discourse (Walsh as quoted in Alsubaie, 2015). In teaching speaking, questions are very often posed by the lecturers in order to make students speak and to check their understanding. In this case, WH questions should be posed more often to which the students can provide long answer and have more opportunities for practicing the target language.

Many things can be elicited from students by using gapped sentences on the board to lead them to discover something, to encaurage thinking, and 
Usman, Ayouni, Samad, Fitriani, Teachers' Elicitation: Inviting Students ...

guide discovery (Scrivener, 2012). This makes them alerted to keep thinking and searching for answer to fill in the gap. Additionally, Coskun (2010)) proposed that correct form can be directly elicited from students by pausing to allow them to complete the utterance such as "He is good...?". This provokes their curiosity and attention to give the expected answer. Some features like grammatical form, vocabulary, and how they pronounce the words can be identified from their response.

Alternatively, non-verbal language can be utilized as well. So, miming, gestures, facial expression, and body language are usually exploited to elicit words and language structure (Doff as cited in Sasmita, 2013). This provides students clues so that they will be easier to find appropriate response. Beside, when effectively generated, eliciting by using gesture makes learning more interesting. It avoids students from being bored because the lecturers use various technique in inviting them to speak.

In a nutshell, elicitation techniques include both verbal and nonverbal. It is done mainly using questions to which students gives answer and is evaluated by the lecturer. Body language or gesture, gapped sentence, and strategic pausing can also be implemented to elicit their response.

The researcher had based the anlysis of this study on Tsui's (1995) classification of elicitation which is function-based. Tsui adopted the term elicitation from Sinclair and Coulthard who was for the first time use it to refers to any utterances which expect students' verbal response. She further classified it into six types as appear in the following (as cited in Jafari, 2013)

Elicit:inform

It invites students to supply a piece of information. This kind of elicitation can be realized by using WH questions, yes/no question, alternaticve question, and indirect question.

Elicit:comfirm

This subcategory invites students to confirm teachers' assumption. For example to confirm whether they had understood the material or not. It can be realized by tag interrogative, declarative, and negative polar question.

\section{Elicit:agree}

Elicit:agree is functioned to ask for students' agreement towards teacher's assumption which is sefl-evidently true. It can be applied by using tag question.

\section{Elicit:commit}

This kind of elicitation is to elicit commitment from students. Yes/no question and WH interrogative may be used in elicit:commit.

\section{Elicit:repeat}

This category prospects a repitition of the utterance preceeding elicitation. It invites students to repeat their response because the teacher has not heard it clearly. It is identified by $\mathrm{WH}$ questions, 


\section{EduLite}

utterances like "say it again, pardon?, sorry?, could you reapeat? or huh?

\section{Elicit:clarify}

It requests for students' repitition of previous utterance because it was incorrect, so that they will be aware of their mistake. It is known by WH interrogative or high key repitition of a word or phrase in the preceeding utterance.

The use of elicitation in speaking class is aimed at motivating students to speak and train their use of grammar, vocabulary, pronunciation and fluency. Due to this, some steps must be taken into account to successful elicitation. Scrivener (2012) suggested several important points to effective eliciting, they are as follow:

a. Make sure the class can hear both the question and the answer. It is important that everyone can hear answers given by other student.

b. Use a natural sounding. Questions sound more inviting if it sounds like you really search for the answer.

c. Consider a wait-time where it allows students to think, don't hurry them and don't answer your own question.

d. Questions can be nominated. Ask the questions by calling out their name one by one. If a student can not provide the answer, ask to another one.

In addition, according to Darn (2010) elicitation can be done effectively by following the some suggestions below:

a. Don't ask students to repeat the incorrect answer, but ask different students to repeat the correct one. This helps them remember.

b. Give feedback for each answer with comments or gesture because it can encaurage and motivate them to learn more.

c. Eliciting is designed to find out what students have already know. So, they should be provided with sufficient context and information.

d. Use more guided question to lead students to an expected response.

There are many advantages of elicitation in the second language classroom, they are:

a. It makes students more attentive to the topic being presented by the lecturers.

b. It helps the lecturers to find out how well they apply language structure, vocabulary, and appropriate pronunciation in speaking.

c. It maximises speaking opprtunities

d. It is to check students' understanding. 
Usman, Ayouni, Samad, Fitriani, Teachers' Elicitation: Inviting Students ...

However, if overused, some advantages of elicitation may be lost. Here are possible disadvantages of eliciting in language classroom based on Case (2009)

a. Eliciting can just be a wasting-time procedure.

b. An active student can dominate the class to answer all of elicitation.

c. If they don't have any idea, elicitation can be met by silence.

d. Eliciting will make boring when they get repititive questions.

\section{DISCUSSION}

This descriptive study is done under quantitative and qualitative method. The combination of both give comprehensive description of the study and are very important in second language education (Richards and Nunan, 1990). Quantitative approach involves numerical measurement and statistical analysis and qualitative method entails description of classroom behaviours and classification (Chaudron, 1988)

This study was conducted at English Department of Ar-raniry Islamic State University (UIN Ar-raniry). 5 lecturers who were teaching speaking took part as research particpants. Hence, 5 speaking classes with 2 meetings for each were observed and recorded from November 12, 2016 until December 10, 2016. The ten teaching sessions were transcribed and used for analysis of teachers' elicitation and IRF pattern.

In order to collect quantitative and qualitative data for this study, some instruments were employed; observation, observation sheet, interview guide, and field note.

\section{Technique of Data Collection}

The data were mainly collected by observation. Additionally, interview was implemented as secondary data which supports observation findings. Techniques of data collection from observation included recording, transcribing, observation sheet, and field note. Recording serves as a potential and rich source of data because it can provide samples of actual teaching (Richards and Nunan, 1990). Therefore, the researcher made audio-video recordings of 10 speaking classes to catch all teachers' elicitations both verbal and nonverbal.

Next, transcribing was done to change recorded data into written form. One advantage that transcript have over video or audio material is that they permit detailed inspection and analysis more easily. Of course, they must be in conjunction with transcripts (Richards and Nunan, 1990). Further, observation sheet was filled to indicate the occurence of types of elicitation during observations. Field notes was also taken to cover some information unfold from the recordings. This observational field note contained details such as name of the the class, semester, time, topic, number of students, setting arrangement.

In addition to observation, the researcher interviewed two lecturers of research participants to get some information about elicitation in speaking class. Hence, some questions were asked to reflect on their implementation of elicitation in teaching speaking. Interview which was done after observation was also recorded to avoid possible misunderstanding and transcribed to ease the analysis. 


\section{EduLite}

Journal of English Education, Literature, and Culture

Volume 3, Number 1, February 2018

Technique of Data Analysis

Data analysis is the process where the researcher analyzed the collected data to be arranged, organized, managed, and take conclusion. It was accomplished in two stages; During-data collection and post-data collection. Therefore, techniques of data analysis followed in during-data collection was Miles \& Huberman's model (1992) which includes data reduction, data display, and conclusion/verification.

Data reduction is the phase where the raw data were reduced for choosing the main data, focusing on important ones, and searching for the concepts and model by reviewing the result of observation and reading the interview findings. This activity allows researcher decide whether the data is needed or not, it this case, it is searching for teachers' elicitation and classifying it to Tsui's type of elicitation.

Data display is the important stage which serves to display the observation and interview findings. After segmenting the transcipts into Tsui's type of elicitation, the data were displayed with some examples taken from the entire data and shown in the discussion.

Finally, meaning and interpretation were given to the result to draw conclusion and verification. In this section, the researcher found out the answer for first and second research question; What kinds of elicitation are used by the lecturers in speaking class of English Department of Ar-raniry Islamic State University?

The next phase is post-data colection in which the analyzed data were reanalyzed to avoid mistakes and counted to reveal quantitative data. The most frequent type of teachers' elicitation in speaking classes were identified by using percentage formula as proposed by Arikunto (2006:123):

$$
\mathrm{P}=\frac{f}{n} \times 100 \%
$$

Where:

P: Percentage

$f: \quad$ Frequency

n: Number of students

After following some tehniques of data collection and analysis, significant number of teachers' utterances in 10 speaking classes were classified into six types of elicitation by Tsui (1995). And, its exchange was applied to S\&C IRF structure. The frequency of each type was also reported in the discussion. Only some examples presented in the discussion, other remain as appendices.

The Type Elicitation Used by the Lecturers in Speaking Class

After the process of data reduction of the transciptions, teachers' elicitation employed by the lecturers in speaking class covers the six types; Elicit:inform, elicit:confirm, elicit:agree, elicit:commit, elicit:repeat, and elicit:clarify. It means that the lecturers conducted all types of elicitation in teaching speaking. As previously mentioned, Tsui's classification of elicitation is formulated based on its function referring to any teachers' utterance to elicit verbal response. Each of them is duscussed in the extracts below: 
Usman, Ayouni, Samad, Fitriani, Teachers' Elicitation: Inviting Students ...

\section{Elicit:inform}

T: Sandwich is a countable noun. Sandwiches for more than one. Sandwich only for one. Do you see more than one sandwich?

Ss: Just two.

T: So you will say?

Ss: Sandwiches.

T: Sandwiches.

The extract above shows the lecturer elicited students' correct use of a grammatical item (countable/uncountable noun) which is indicated in the utterances "Do you see more than one sandwich?" and "So you will say?". Therefore, the students were aware to use correct structures in their speaking. The teacher's elicitation lead them to discover it by themselves rather that provide it for them.

T: $\quad$ Alright. ....what to say...the seller of tahu....how to say tahu in English?

Ss: Tofu...

$\mathrm{T}$ : Alright.

An elicitation is a procedure for the lecturers to present meaning of words (Thornbury, 2013:87). The utterance in the opening move "how to say tahu in English?" is considered as Elicit:inform which elicits the meaning of tahu in English.

\section{T: If you go swimming, what kind of cloth you wear? \\ Ss: Gym suit. \\ T: $\quad$ Okay good. Go on.}

Elicit:inform in vocabulary is also demonstrated in the extract 1.3 in which a display question "If you go swimming, what kind of cloth you wear?" is a teacher's elicitation to ask student to supply the target language words "Gym suit". The lecturer elicited it instead of telling it.

T: What you call this? (the lecturer used gesture)

Ss: Thread mill.

T: $\quad$ Thread mill

Many ways can be explored to elicit student's vocabulary in speaking class. Doff (in Sasmita, 2013:4) stated that miming, gestures, facial expression, and body language are used mainly to elicit new vocabulary and structure. Extract 1.4 illustrated that students are introduced to name of sport equipments, so the lecturer used his gesture to elicit the word. It makes them easy to give the expected answer.

T: Kilograms. So what we call this? (the lecturer drawn pictures)

Ss: Burble. 


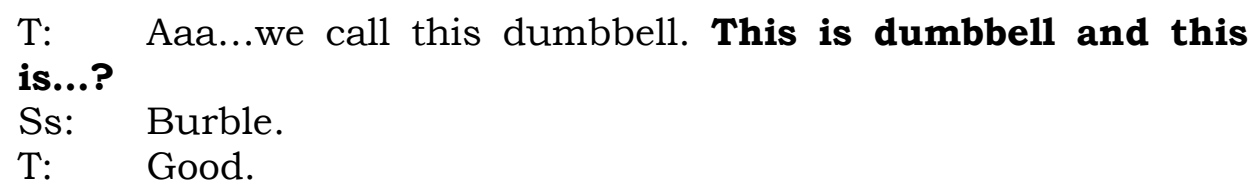

The data above is elicit:inform by pictures and gapped sentence to request students' vocabulary. The lecturer drawn a picturer on white board and asked "So what we call this?". Further, in his second turn, he used strategic pausing in eliciting. It is pointed in "This is dumbbell and this is...?. The lecturer can directly elicit by pausing to allow students to complete his utterance (Coskun, 2010:27).

\section{T: What is pull of? Pull of. \\ Ss: Stop. \\ T: Stop the?}

Ss: Car.

T: Stop the car. Okay, pull your car of. In tatters? (pointed to the white board).

Ss: Ripped.

T: Yes. Ripped everywhere. Ripped here ripped here ripped here everywhere. Now pale.

Ss: Pucat.

T: It doesn't look healthy right?

Elicitation of appropriate functional language can be reached by asking question, using synonysm, etc (Lindsay in Syauqi, 2011:19) as pictured in the first lecturer's question "what is pull of?" which requested for synonym of pull of "stop". Next, his utterances "in tatters" and "now pale" are also categorized as elicitation. Although they were not in form of questions. The lecturer funtioned them to elicit students' response. Since the students are giving verbal responses triggered by the teacher's opening, it is called elicitation (Dailey, 2010:10).

\section{T: Alright. Okay. So what do you think?}

Sf: The gangster is so arrogant aaa and do the bullying to other people around him aaa so aaa when he see the seller no response to him aaa just so so, he just say oh my goodness, he is more stronger than me. And she... and he can't say anything.

T: Okay. At the end. Ya. You what do you think about the gangster behavior?

Many ways can be implemented to elicit responses for example questioning, strategic pausing, student-direct activities, and using visuals (Alsubaie, 2015:30). The lecturers in speaking often elicit ideas, information, and feelings from students after watching videos. Therefore, teacher's elicit:inform to invite their opinion can be seen in the question "So what do you think?". This activity opens opportunity for practicing English speaking. 
Usman, Ayouni, Samad, Fitriani, Teachers' Elicitation: Inviting Students ...

\section{Elicit:confirm}

T: Okay. So please make conclusion, and please tell us what happen in the story and then what is the advantage of this movie? Understand me?

Ss: Yes.

T: Yes. Alright.

This type of elicitation is often to check students' understanding, hence, the lecturer invite them to confirm his assumption if they understood his explanation or not. It can be identified by yes/no question which can be seen in "Understand me?". It allowed the lecturer to continue the next lesson.

Elicit:agree

$\mathrm{T}$ : And they decided not to go to the gym anymore, right?

S: Yes.

T: When they see the bill, were they shocking or were they shocked?

Elicit:agree also appeared in the lecturer's utterance "And they decided not to go to the gym anymore, right?". Using a tag question, he invites students to agree with his assumption which was self-evidently true based on the story.

Elicit:commit

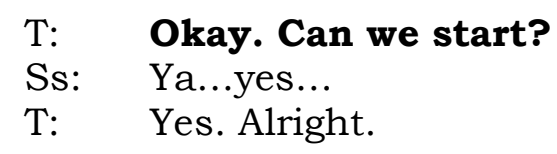

Extract above was recognized as elicit:commit due to its request for commitment (Tsui in Jafari, 2014:3). Lecturers usually deals with student to make some commitment in the classroom for example stating commitment to begin the lesson as signified in utterance "Okay, can we start?". Lecturer's question is to elicit students' response so that he know whether the class is ready to begin.

\section{Elicit:repeat}

\section{T: $\quad$ Pardon?}

S: $\quad$ The woman... the young woman changed to the scary face. And she laugh like a ghost.

T: $\quad$ So her face turn ugly ya?

Lecturer's words which functions to ask for repition is called elicit:repeat which can be expressed by "who/when/where/what did you say?, "say that again", "sorry?”, "pardon?”, or "uh?” (Tsui as cited in 
Jafari, 2013:3). It is as reflected in the first line of the extract above:"pardon?".

Elicit:clarify

S: Guitar two.

T: Say it again?

S: $\quad$ Guitar...I have two guitars. And then one more is ukulele.

T: Ukulele...?

After a student's response, the lecturer found incorrect form and he invited her to repeat it again by utterance "Say it again?". This elicitation makes the student aware of her mistake "guitar two". Then, she came up with the accurate one as indicated in "I have two guitars", instead of previous answer "guitar two". This kind of elicitation is requesting repitition because of incorrect answer.

In a nutshell, elicitations used in speaking class included all types of elicitation by Tsui (1995). It was exploited to elicit grammatical forms, vocabulary, word meaning, and ideas from students in order to train their speaking. As well, it is a toll for checking understanding, leading to self-discovery and corection, and increasing students' talking time. Techniques for eliciting were mainly questions, others were gesture, picture, strategic pausing or gapped sentence.

Elicitation is very essential in teaching speaking. This was confirmed by interview findings:"That's how we get them to speak. Mmm that's how we motivate them to speak. That's we asses whether they are motivated to speak, whether they are encauraged to speak or not" (See appendix 13). Further, it was supported by lecturer's stament: "Yes, that the first thing to have to do to find their error grammar. We have to correct it by elicitation".

The Most Frequent Type of Teachers' Elicitation in Speaking Class

To search the most frequent type of elicitation happened in speaking class, a quantitive process was applied using percentage formula. The result is that Elicit:inform placed the highest frequency with the total number 359 out of 497 which reached $72.23 \%$. It means that Elicit:inform is the most frequent type of elicitation used by the lecturers in speaking class of .

The second most frequently used elicitation was Elicit:agree which has 48 frequencies $(9.66 \%)$. Further, Elicit:confirm occured 39 with the percentage $8.14 \%$. Next was Elicit:repeat which was employed $4.38 \%$ (21) or slightly higher than Elicit:clarify which appeared $4.02 \%$ (20) of the whole types of elicitation. Meanwhile, Elicit:commit was the least frequently used that takes merely 10 frequencies and $2.0 \%$. Each frequency was served in the following table.

Table 1

The Frequency and Percentage of Elicitation Used in Speaking Class 
Usman, Ayouni, Samad, Fitriani, Teachers' Elicitation: Inviting Students ...

\begin{tabular}{|c|c|c|c|c|c|c|c|c|c|c|c|c|c|}
\hline \multirow{2}{*}{ No } & \multirow{2}{*}{$\begin{array}{l}\text { Types of } \\
\text { Elicitation }\end{array}$} & \multicolumn{10}{|c|}{ Observation } & \multirow{2}{*}{$F$} & \multirow{2}{*}{$\%$} \\
\hline & & 1 & 2 & 3 & 4 & 5 & 6 & 7 & 8 & 9 & $\begin{array}{l}1 \\
0\end{array}$ & & \\
\hline \multirow[t]{2}{*}{1} & Elicit:inform & 9 & 3 & 8 & 9 & 3 & 8 & 4 & - & 1 & 4 & \multirow[t]{2}{*}{359} & \multirow[t]{2}{*}{$72.23 \%$} \\
\hline & & & 2 & 8 & & 6 & 7 & 4 & & 4 & 0 & & \\
\hline 2 & Elicit:confirm & $\begin{array}{l}1 \\
5\end{array}$ & 8 & 3 & - & 4 & 3 & - & 6 & 2 & - & 39 & $8.14 \%$ \\
\hline 3 & Elicit:agree & 1 & 7 & 7 & - & 5 & $\begin{array}{l}1 \\
3\end{array}$ & 2 & - & 8 & 5 & 48 & $9.66 \%$ \\
\hline 4 & Elicit:commit & - & 7 & 3 & - & - & - & - & - & - & - & 10 & $2.0 \%$ \\
\hline 5 & Elicit:repeat & - & 1 & 5 & - & 1 & 8 & - & 1 & 1 & 4 & 21 & $4.38 \%$ \\
\hline 6 & Elicit:clarify & - & 2 & 6 & - & 4 & 5 & 1 & - & - & 2 & 20 & $4.02 \%$ \\
\hline \multicolumn{12}{|c|}{ Total } & 497 & $100 \%$ \\
\hline
\end{tabular}

\section{CONCLUSION}

Based on data anlysis, the lecturers used all type of elicitation in speaking classes, namely elicit:inform which was the most frequent type employed, elicit:confirm, elicit:agree, elicit:commit, elicit:repeat, and elicit:clarify. Elicitation is important in developing students' speaking skill. Therefore, lecturers should be more aware of using it for their speaking improvemnet. Some important points including feedback, nomination, clear voice, and a wait-time need to be implemented for succesfull elicitation. Various techniques of elicitation other than questions like body language, gap sentence, strategic pausing should be utilized to elicit students' talk.

WH-questions should be exploited more often to which students can give long answer instead of short yes/no response. Thus, it opens more opportunities for them to use and practice their English speaking. Additionally, the lecturers or teachers should consider a wait-time to give students a space to think and reformulate their responses when getting no answer. Thus, nominating, rephrasing questions, and clue are needed to elicit again instead of telling them the correct response or answering own questions.

\section{REFERENCES}

Arikunto, S. (1991). Prosedur penelitian. Jakarta: Rineka Cipta.

Case, A. (2009). The advantages and disadvantages of eliciting in the EFL Classroom. Retrieved March 10, 2016 form http:/ / www.usingenglish.com/teachers/articles/advantagesdisadvantageseliciting-in-efl-classroom.html.

Chaudron, C. (1988). Second language classroom. Cambridge: Cambridge University Press. 


\section{EduLite}

Journal of English Education, Literature, and Culture

Chitravelu, N., Sithamparan, S., \& Choon, T.S. (2005). ELT methodology: principle and practice. Selangor: Fajar Bakti.

Coskun, A. (2010). A classroom research study on oral correction. Retrieved March 10, 2016 from http://www.hltmag.co.uk/jun10/sart05.htm.

Darn, S. (2009). Eliciting. Retrieved April 4, 2016 from http://www.teachingenglish.org.uk/article/eliciting.

Goh, C.C.M \& Burns, A. (2012) Teaching speaking: A holistic approach. New York: Cambridge University Press.

Harahap, H.S. (2010). Elicitation and feedback in English classroom interaction in biology teaching in the international standard class of State Senior High School 1 Medan. Retrieved March 14, 2016 from http://digilib.unimed.ac.id/public/UNIMED-Master-1146072188330015\%20bab\%20II.pdf.

Harmer, J. (2007). The practice of English language teaching: Fourth Edition. New York: Pearson Longman.

Islamiyah, M. (2012). Elicitation technique in questioning used by content and language integrated learning classroom teacher: A Qualitative Study. Retrieved March 10, 2016 from http://repository.upi.edu/id/eprint/9156.

Jafari, J. (2014). The role of elicitation questions in language learning: A function-based framework. Hamburg: Anchor Academic Publishing.

Luoma, S. (1999). Assessing speaking: Cambridge language assessment Series. Cambridge: Cambridge University Press.

Miles, M.B., \& Huberman, A.M. (1992). Analisis data kualitatif. Jakarta: UI Press.

Nathan, M. J \& Kim, S. (2007). Regulation of Teacher Elicitations and the Impact on Student Participation and Cognition. Retrieved November 8, 2015 from http://www.wcer.wisc.edu/.

Nurokhmah, M.I (2009). Elicitation technique used by teacher to encourage students' talk. Retrieved October 10, 2017 from https://id.123dok.com/document/z1d7253z-elicitation-techniqueused-by-teacher-to-encourage-students-talk-a-case-of-english-teachersof-sma-n-3-semarang.html.

Nunan, D. (1999). Second language teaching and learning. Boston: Heinle \& Heinle Publisher. 
Usman, Ayouni, Samad, Fitriani, Teachers' Elicitation: Inviting Students ...

Pearson, T. (2016). The Structure of L2 Classroom Interaction.Retrieved July 7, 2017 from http://docplayer.net/21089709-The-structure-of-12classroom-interaction.html.

Ramiro, S.R. (2002). The significance of certain prosodic feature in the discourse of the teacher in EFL classroom. Retrieved March 22, 2016 from http://www.cvc.cervantes.es.

Richards, J.C \& Nunan, D. (1990). Second language teacher education. Cambridge: Cambridge University Press.

Richards, J.C., \& Farrel, T.S.C. (2011). Practice teaching. Cambridge: Cambridge University Press.

Sasmita, Delvia., Jufri \& Triana, Yuli. (2017). An analysis of teachers' elicitation techniques in the classroom at SMA Pembangunan Laboratorium UNP. Retrieved January 12, 2017 from http:/ / repository.upenn.edu/cgi/viewcontent.cgi?article=1283\&context $=$ wpel.

Scrivener, J. (2012). Classroom management techniques. Cambridge: Cambridge University Press.

Syauqi. (2011). Teaching speaking by using games. Thesis. Banda Aceh: Syiah Kuala University.

Thornbury, S. (2005). How to teach speaking. Harlow: Pearson Education Limited. 